\title{
FOCUS ON ECOLOGY IS A GOOD DEED
}

\author{
Kurbanova Dilshadkhan \\ Associate Professor of Andizhan branch of Tashkent State Agrarian University, PhD in History, \\ Republic of Uzbekistan
}

Article DOI: https://doi.org/10.36713/epra3931

\begin{abstract}
The article analyzes the fact that the problem of environmental security has become a national problem of all mankind, going beyond the national and regional framework, environmental protection measures with the help of scientific literatures.
\end{abstract}

KEY WORDS: ecology, environment, humanity, religion books, land, water, transportation.

\section{INTRODUCTION}

The fact that Earth, Water, Air and Fire are among the greatest blessings of human existence is recorded in the Book of the Avesta, written on the land of ancient Turan 30 centuries ago. But even though this ancient document consists of compiled texts, fire, air, water, earth, which are described as sacred elements in the book, and their greatness are narrated in the pamphlets available in mysticism and theology. According to religious books, before the creation of the world, Allah's command to Nuri Muhammad was based on divinity. We all know that because there was no arrogance in the soil, Hadrat Adam chose to create Adam from this soil. Therefore, the nature of every human being is not devoid of four substances [1, p.6]. In some people, grass is strong, in some, water, in some, wind, and in some, soil predominates.

\section{METHODS}

In fact, the slaves who have tried to keep these four substances clean since the creation of the universe have kept them clean, because each of us must recognize that our bodies are made up of these elements, that our lives depend on the purity of these substances, and that we live by them. In ancient times, the Avesto described the laws of punishment against the pollution of these sacred substances, which were the first manifestations of neglect of these sacred substances.

\section{RESULTS AND DISCUSSIONS}

Our wise and intelligent ancestors carefully preserved the sanctity of the soil and brought it to the XXI century, so that maintaining its fertility and effective use of land has become an urgent task today. The problem of environmental security has already gone beyond the national and regional framework and become a common problem of all mankind. According to a study by the Club of Rome entitled "The Way of the XXI Century", economic activity, which does not take into account the possibilities of human nature and the laws of its development, has led to soil erosion, deforestation, overfishing, salt rains, atmospheric degradation and other negative consequences.

1. Soil issue: Experts estimate that in 2000, forests accounted for $1 / 6$ of the land area, compared to $1 / 4$ in the $1950 \mathrm{~s}$.

2. Water problem: The waters of the world's oceans are being catastrophically polluted, and its recyclability is declining sharply. Non-stop shipping, oil spills, and industrial wastewater are damaging the sanctity and healing of water.

3. Air issue: The ever-growing arms race poses a major threat to the human habitat in the production, storage and testing of nuclear, chemical weapons and other types of weapons of mass destruction.

4. Fire problem: It is a great disaster that fires coming out of the pipes of heavy enterprises can be seen from a distance of several kilometers. The gases that go into the hills to burn lime in the houses, or the many gases that burn carelessly in the houses, 
are useless to nature. Harm to human health and other circumstances are some examples of how we neglect good deeds.

In recent years, environmental problems in the Asian region have become increasingly acute [2, p.78]. Therefore, at a meeting in Tashkent on January 4, 1993, a meeting of the International Fund for Saving the Island was held and the foundation was laid. The program was developed in 1994 and 2002. It is no secret that in Uzbekistan, one of the largest countries in the region, the environmental situation is deteriorating as a result of the rapid development of all sectors of the economy. As a result, there is a relative increase in various infectious, oncological, allergic diseases. Therefore, the First President of our country I.A. Karimov in his works "Uzbekistan aspires to the XXI century" and other works paid great attention to environmental protection.

The ecological condition of cities is much more complicated than that of rural areas. The main source of urban pollution is the abundance of motor transport and the energy sector. It is the right way to use natural resources to prevent the negative impact of the transport and energy sectors on the environment. We believe that in order to implement environmental protection in such a multifaceted way, it is necessary to know the activities of environmental protection and how to provide it with funds, that is, the introduction of environmentally friendly technologies, demand and proper organization of production. It is the urgent task of today to pay more attention to the issue during the global financial and economic crisis $[3, \mathrm{p} .77]$.

The need to establish a common partnership between economic growth and environmental change is, of course, rooted in environmental protection. To this end, a program has been developed and is being developed by a number of expert scientists. The government place of Andizhan region pays great attention to the implementation of programs designed for socio-ecological beautification and protection of public health. In this regard, a number of seminars held in 2009 in Andijan region with the participation of specialists of the Republic. It is recommended that the purpose, timing and phase of the program be provided with a list of key activities, executors and results for the implementation period, a control system. The program recommends a number of measures to save the Andijan region from environmental crisis. The main goal is to improve environmental protection, restore natural compounds, improve the health of the population and create favorable conditions, prolong the life of the population.

The Women's Committee of Andijan region and the Association of Women Scholars are taking serious practical measures to restore women's reproductive health. The region is one of the areas equipped with pipelines. Piping is the most environmentally friendly means of transportation, but it is also harmful to the atmosphere. For example, improper connection of gas pipes and gas leaks as a result of various accidents have an impact on the environment. There are more than $50,000 \mathrm{~km}$ of gas and oil pipelines in the region. Another source of pollution is large livestock complexes. They had almost no access to air purification facilities. According to the program, polluted farms are currently focusing on the issue of work [4, p.56].

The results of the analysis of the condition of rivers, streams, canals and ditches passing through the territory of our region show that the banks of the water protection zone are not protected. The rivers and canals are dug up to the water level. Thus, the leakage of mineral fertilizers and pesticides as a result of water washing away the soil leads to water poisoning. In addition, there are cases when various wastes and animal wastes are added to the water of livestock complexes. From the above, water pollution conditions in turn have an impact on the quality of drinking water, which leads to a violation of the standard requirements of the physicochemical bacteriological index of drinking water composition. Pollution is increasing in catchments, such as reservoirs.

The high emergency condition of networks, water leaks and cracks in the foundations of buildings as a result of currents, excessive waste of electricity, deterioration of the bacteriological and toxic state of water lead to many infectious diseases, resulting in a profound impact on the nation's gene pool. Women make up more than $50 \%$ of the population. The region is the largest agricultural region in the country $75 \%$ of the land is mainly used for agriculture.

It is polluted by oil products, salts, pesticides, heavy metals. In some areas, the amount of iron, nickel, chromium, copper exceeded the permissible norm. One of the most pressing environmental issues in our region is the growing amount of production and household waste. Excluding from organizations and special processing, the total amount of household waste, including more than 10 million tons. There are more than 400 landfills in the region, covering an area of about 1,000 square meters, and the collection of industrial and local waste is adapted to standard-sanitary requirements. But the lack of sorting and attention to the types of waste collected complicates their disposal and recycling technologies. As a result of the release of these wastes into the atmosphere, toxic compounds are added to groundwater and become a source of disease. In addition, street cleaners are sweeping the rubbish into running water, causing great damage to cleanliness. After all, our ancestors from ancient times considered it their sacred duty to keep water, soil and air clean. At a time when the 
process of reviving ancient traditions is approaching, attention to these issues is one of the main tasks of the beginning of the XXI century. That is why many species of spruce trees are being planted at the initiative of the regional administration.

Maintaining the purity of the environment is becoming increasingly important. At the International Summit on Saving the Aral Sea in Bishkek on April 28, 2009, First President of the Republic of Uzbekistan Islam Karimov said that the level of the Aral Sea had decreased by 4 times and its water level by 10 times. On May 7, 2009, guests led by the President of the World Water Council Luis Fashon visited Uzbekistan. The Ministry of Agriculture and Water Resources of Uzbekistan held talks chaired by I. Karimov. During the talks, it was noted that water scarcity has become a topical issue in many countries today. Improving the management and efficient use of water resources will not only ensure the sustainable development of agriculture and food security, but also improve human health, protect the environment and maintain ecological balance.

\section{CONCLUSION}

We must always remember that the purity of the Fire, the Air, the Water, and the Earth, which was warned in the Avesta 3,000 years ago, is the basis of the belief in the purity of the bodies of children born today and in the future. It is the duty of all of us to do good deeds such as protecting the environment, not to be indifferent to the dumping of various wastes into the water, the burning of various kinds of garbage, and so on, because the time has a future. We think that it is a good deed of conscious, thinking people to take care of it, teach it to young people and pass it on to them.

\section{REFERENCES}

1. Murtazaeva R.Kh. Interethnic relations and tolerance in Uzbekistan. -Tashkent: University, 2007.

2. The Constitution of the Republic of Uzbekistan. Tashkent: Uzbekistan, 2014.

3. The New History of Uzbekistan. History of independent Uzbekistan.-Tashkent: Shark, 2000.

4. Uzbekistan - Our Common Home // edit. M. Nurmatova. -Tashkent: Uzbekistan, 2001. 